\title{
Pengaruh Astronomi Islam pada Masa Golden Age Terhadap Arsitektur
}

\author{
Iga Nur Ramdhani ${ }^{1^{*}}$, Revianto Budi Santosa ${ }^{2}$ \\ ${ }^{1}$ Magister Arsitektur Universitas Islam Indonesia, ${ }^{2}$ Jurusan Arsitektur Universitas Islam Indonesia \\ 1*Email: 20922003@students.ac.id
}

\begin{abstract}
The science of astronomy in the golden age until now continues to be a conversation, then this scientific field is often associated with a variety of other related sciences. So the topic of the relationship between the science of astronomy in the golden age with the architecture interesting to discuss. To determine whether there is an astronomical influence on the field of architecture. The author conducted research through qualitative descriptive methods, and techniques of data collection study literature review. The author finds some aspects of architecture that can be connected with astronomy. Then we conclude that there are aspects that explain the implications of astronomy to architecture, that are the direction of Qibla in the mosque, and influence the direction of the wind against other public buildings. This study suggests that scientists and practitioners in the field of architecture architects can continue to develop innovations and science of architecture associated with astronomy in the future.
\end{abstract}

Keywords : Golden Age, Astronomy, Architecture

Artikel Info

Received:

05 Mei 2021

Revised:

08 Mei 2021

Accepted:

20 Mei 2021

Published:

08 Juni 2020

\begin{abstract}
Abstrak
Ilmu pengetahuan tentang astronomi pada masa golden age hingga kini terus menjadi perbincangan, kemudian bidang keilmuan ini seringkali dihubungkan dengan berbagai ilmu lain yang terkait. Maka topik mengenai hubungan antara ilmu astronomi pada masa golden age dengan arsitektur menarik untuk di diskusikan. Untuk mengetahui apakah terdapat pengaruh astronomi terhadap bidang arsitektur. Penulis melakukan penelitian melalui metode deskriptif kualitatif, dan dengan teknik pengumpulan data dari studi kajian pustaka. Penulis menemukan adanya beberapa aspek arsitektur yang dapat dihubungkan dengan ilmu astronomi. Kemudian kami menyimpulkan bahwa terdapat aspek yang menjelaskan adanya implikasi astronomi terhadap arsitektur, yaitu arah kiblat pada masjid, dan pengaruh arah mata angin terhadap bangunan umum lainnya. Studi ini menunjukkan bahwa para ilmuwan dibidang arsitektur dan para praktisi arsitek dapat terus mengembangkan inovasi dan ilmu pengetahuan arsitektur yang dihubungkan dengan astronomi di masa mendatang.
\end{abstract}

Kata Kunci : Masa Keemasan, Astronomi, Arsitektur 


\section{AL-MARSHAD: JURNAL ASTRONOMI ISLAM DAN ILMU-ILMU BERKAITAN \\ ISSN 2442-5729 (print) || ISSN 2598-2559 (online) \\ http://jurnal.umsu.ac.id/index.php/almarshad \\ DOI: //doi.org/10.30596/jam.v7i1.6888 || Vol. 7, No. 1 Juni 2021}

\section{A. Pendahuluan}

Ilmu pengetahuan tentang astronomi pada masa golden age hingga kini terus dikembangkan di seluruh dunia, dan dapat dihubungkan dengan berbagai ilmu lain yang terkait. Beberapa diantaranya seperti ilmu teknologi dan inovasi, ilmu sosial-intelektual, dan ilmu pendidikan Islam.

Zaman keemasan Islam atau The Golden Age of Islam berada pada masa kebangkitan Dinasti Abbasiyah yang mulai berkuasa selama 5 abad, yaitu pada tahun 132-656 H dan bertepatan dengan tahun 7501258 M. Kemajuan pada masa Dinasti Abbasiyah berfokus pada kemajuan ilmu pengetahuan dan penyelesaian masalah di dalam negeri. Pada masa ini dilakukan penerjemahan dan penyerapan ilmu dari peradaban lain dengan menerjemahkan bukubuku dari berbagai bahasa (Yunani, Syria, Sansekerta, Cina dan Persia) ke dalam bahasa Arab dalam waktu tiga fase. Fase yang dimaksud yaitu sebagai berikut : 1,2

1) Fase Pertama (132H/750M - 132H/847M), diterjemahkannya karya-karya dalam bidang astronomi pada khalifah alMansyur hingga Harun al-Rasyid.

\footnotetext{
1 Anto Aprianto, 'Kesejahteraan Umaan Dan The Golden Age of Islam Telaah Historis Pemberdayaan Masyarakat Di Masa Khalifah Harun Al-Rasyid', ICODEV , 1.1 (2020).

2 H. Fuad Riyadi, 'Perpustakaan Bayt Al Hikmah "The Golden Age of Islam", LIBRARIA: Jurnal Perpustakaan, 2.1 (2014).
}

2) Fase Kedua (232H/847M - 334H/945M), diterjemahkan buku-buku dalam bidang filsafat dan kedokteran pada masa khalifah al-Makmun.

3) Fase ketiga (334H/945M - 347H/1005M), fase mulai untuk menyaring menganalisis dan menerima atau menolak pengetahuan dari peradaban lain.

Astronomi Islam yang berkembang pada masa golden age memberikan dampak pada perkembangan ilmu teknologi, salah satunya adalah penemuan teleskop. Terdapat tiga jenis teleskop yang berkembang, yaitu teleskop optik, teleskop lensa, dan teleskop radio. ${ }^{3}$ Hingga kini teknologi terus berkembang sehingga selain tiga teleskop tersebut, terdapat teleskop berbasis komputer. Teleskop yang dimaksud adalah yang dilengkapi dengan motor penggerak otomatis yang tersambung dengan komputer. Teknologi tersebut semakin dikembangkan salah satunya dihubungkan pada aplikasi KStars. Aplikasi ini menghubungkan teleskop yang terkomputerisasi dengan teknologi sistem operasi open source. ${ }^{4}$

Di bidang sosial dan intelektual, astronomi memberi kontribusi dari adanya

\footnotetext{
${ }^{3}$ Irvan dan Leo Hermawan, 'Mengenal JenisJenis Teleskop Dan Penggunaannya', Al-Marshad, 5.1 (2019).

4 Adi Damanhuri, 'Sistem Kontrol Teleskop Meade LX-600 Dengan Aplikasi Open Source', AlMarshad, 5.2 (2019).
} 


\section{AL-MARSHAD: JURNAL ASTRONOMI ISLAM DAN ILMU-ILMU BERKAITAN \\ ISSN 2442-5729 (print) || ISSN 2598-2559 (online) \\ http://jurnal.umsu.ac.id/index.php/almarshad \\ DOI: //doi.org/10.30596/jam.v7i1.6888 || Vol. 7, No. 1 Juni 2021}

observatorium. Observatorium adalah sebuah tempat yang digunakan untuk mempelajari dan observasi benda-banda langit. Observatorium memberi dampak terhadap budaya sosial keagamaan, yaitu terkait dengan posisi serta lokasi ibadah bagi umat Islam. Kemudian secara intelektual, memberikan budaya intelektual terhadap pengkajian ilmu yang lebih ilmiah dengan observasi, penelitian, serta kajian ilmiah. ${ }^{5}$

Keilmuan astronomi dengan observatorium, selain digunakan untuk mempelajari tentang langit, observatorium astronomi juga digunakan untuk ibadah, sosial dan bidang pendidikan. Pada bidang pendidikan keberadaan observatorium astronomi ini memiliki beberapa nilai, yaitu sebagai sarana mengakuratkan waktu dan posisi ibadah, sebagai lembaga pengkajian ilmiah, serta sebagai lembaga pendidikan ilmiah. ${ }^{6}$

Berdasarkan kajian pustaka, ilmu astronomi ternyata memiliki keterkaitan terhadap ilmu pengetahuan lain. Kemudian bagaimana perjalanan kajian astronomi Islam pada masa golden age dan implikasinya terhadap bidang arsitektur.

Perjalanan sejarah kajian astronomi Islam pada masa golden age serta

5 Muhammad Qorib, 'Aspek SosialIntelektual Observatorium Dalam Islam', Al-Marshad, 5.1 (2019). implikasinya terhadap bidang arsitektur perlu diketahui, karena akan menambah ilmu pengetahuan tentang bagaimana pengaruh astronomi terhadap arsitektur. Serta dengan mengetahui hal tersebut, para ilmuwan dibidang arsitektur dan para praktisi arsitek dapat terus mengembangkan inovasi dan keilmuan arsitektur yang dihubungkan dengan astronomi di masa mendatang. Tujuan dari penelitian ini adalah untuk mengetahui peran serta ilmu astronomi terhadap arsitektur. Untuk mengetahui hal tersebut maka peneliti akan melakukan studi kepustakaan yang terkait dengan ilmu astronomi pada masa golden age dan yang memberi pengaruh terhadap arsitektur.

\section{B. Metode Penelitian}

Penelitian ini menggunakan metode deskriptif kualitatif, dan termasuk dalam jenis penelitian kepustakaan. Kemudian pengumpulan data menggunakan teknik studi pustaka dan literatur. Sumber data yang dimaksud adalah buku-buku, jurnal atau artikel ilmiah yang memiliki tema terkait dengan masa golden age khususnya dibidang astronomi serta yang berhubungan dengan arsitektur. Studi kepustakaan ini bertujuan untuk mengetahui perjalanan ilmu astronomi pada masa golden age dan implementasinya

\footnotetext{
${ }^{6}$ Akrim, 'Nilai-Nilai Pendidikan Islam Dalam Observatorium', Al-Marshad, 6.1 (2020).
} 


\section{AL-MARSHAD: JURNAL ASTRONOMI ISLAM DAN ILMU-ILMU BERKAITAN \\ ISSN 2442-5729 (print) || ISSN 2598-2559 (online) \\ http://jurnal.umsu.ac.id/index.php/almarshad \\ DOI: //doi.org/10.30596/jam.v7i1.6888 || Vol. 7, No. 1 Juni 2021}

terhadap keilmuan pada masa kini, terutama di bidang arsitektur.

\section{Hasil dan Pembahasan}

Bosphorus menguasai banyak

kekuasaan di dunia dari abad ke-7, kerajaan Islam dan para anggotanya menyebar dari Arab ke Asia di Timur sampai ke Spanyol di Eropa. Tetapi untuk menaklukkan begitu banyak daerah, mereka harus menjadi navigator hebat. Seluruh peta kuno digambar dengan tangan dan bergantung pada 'pengelana' sebelum masa golden age. Sebelumnya astronom Yunani, Ptolemeus telah mengumpulkan daftar lebih dari 8000 koordinat yang merincikan posisi landmark dan kota lautan. Khalifah Abbasiyah (penguasa kerajaan Islam) dan Al-Mamun cukup berjasa dalam perkembangan ilmu astronomi pada masa golden age. Pada awal abad ke-9 Khalifah Abbasiyah menugaskan sekelompok astronom untuk memperbaiki tabel astronomi Yunani Kuno yang dibuat oleh Ptolomeus. Mereka ditugaskan untuk memperbaiki kesalahan dan membuatnya lebih akurat. Astronomi pada masa kekuasaan Khalifah Abbasiyah dipelajari dan dilihat dalam perspektif kebutuhan beribadah dan dikembangkan sebagai landasan ilmu pengetahuan. Sehingga peradaban Islam melahirkan banyak ilmuwan astronomi, yaitu Al-Battāni， Al-Buzjān̄̄, Ibn Yunus, AthThūsi, Al-Birūni, dan lain-lain. ${ }^{7,8}$

Peradaban Islam seperti India, Cina, Persia, Yunani dan lainnya mempengaruhi berkembangnya astronomi di dunia Islam $^{9,10,11}$

Menurut David A. King, astronomi Islam pada masa golden age diutamakan untuk menentukan sistem kalender, waktu salat, dan untuk menentukan arah kiblat. ${ }^{12}$

Dibawah ini adalah beberapa ilmu yang berkembang dari astronomi pada masa golden age, diantaranya :

1. Teknologi Astronomi pada Masa Golden Age

Terdapat beberapa teknologi yang dikembangkan pada masa golden age. Salah satu ilmuwan yang berkontribusi terhadap teknologi astronomi adalah Ibn al-Syatir. Beberapa teknologi tersebut diantaranya Astrolabe, Sundial, dan Kompas. Astrolabe adalah alat yang digunakan untuk mengukur

${ }^{9}$ Akkach Samer, 'ILM Science, Religion and Art in Islam (Australia: University of Adelaide Press, 2019).

${ }^{10}$ Agussani.

11 Lohlker Rudiger, 'Global History: Understanding Islamic Astronomy.', Acta Via Serica, 4.2 (2019), 97-118.

${ }^{12}$ Agussani. 


\section{AL-MARSHAD: JURNAL ASTRONOMI ISLAM DAN ILMU-ILMU BERKAITAN \\ ISSN 2442-5729 (print) || ISSN 2598-2559 (online) \\ http://jurnal.umsu.ac.id/index.php/almarshad \\ DOI: //doi.org/10.30596/jam.v7i1.6888 || Vol. 7, No. 1 Juni 2021}

kedudukan benda langit. Para ilmuwan pada masa golden age menggunakan alat ilmiah serbaguna yang disebut Astrolabe tersebut. Sebelum penemuan teleskop, Astrolabe merupakan alat yang sangat berguna bagi para astronom pada masa golden age. Sundial merupakan jam matahari. Dalam teknologi ini, Ibn al-Syatir membagi waktu menjadi 12 jam dalam sehari dan menjadi lebih panjang ketika musm panas. Sundial merupakan jam tertua dalam peradaban manusia. Ibn alSyatir juga sebagai salah satu penemu kompas, yang menggabungkan antara jam matahari dengan jam magnetik. ${ }^{13}$

Teknologi lainnya adanya dengan didirikannya Observatorium pada masa golden age yang bernama Observatorium Maragha. Observatorium Maragha menjadi yang terpenting pada masa golden age serta menjadi pusat kolabolasi ilmiah internasional. Observatorium Maragha menarik para ilmuwan dari seluruh wilayah yang dipersatukan oleh ekspansi Mongol. Astronom disana tidak memiliki teleskop, tetapi trik matematika yang mereka kembangkan berpengaruh dalam astronomi selama berabad-abad yang akan datang. ${ }^{14,15}$

${ }^{13}$ Siti Nur Halimah, 'Benang Merah Penemu Heliosentris: Kajian Pemikiran Ibn Al-Syatir', AlMarshad: Jurnal Astronomi Islam Dan Ilmu-Ilmu Berkaitan, 4.1 (2018).
2. Astronomi Mempelajari Tata Surya pada Masa Golden Age

Terdapat tiga teori mengenai pergerakan benda langit, yaitu egosentris, heliosentris, dan geosentris. Egosentris merupakan teori yang menganggap bahwa pusat peredaran dari benda-benda langit adalah manusia itu sendiri. Geosentris pertama kali dikemukakan oleh Ptolomeus. Geosentris merupakan teori yang memiliki pendapat bahwa Bumi merupakan pusat tata surya dan orang Yunani mempercayai hal tersebut. Heliosentris merupakan teori yang menganggap bahwa Matahari adalah pusat sistem benda-benda langit. Di dalam sejarah astronomi Nicolaus Copernicus dikenal sebagai pencetus gagasan tersebut. Namun Edward S. Kennedy menemukan kesamaan antara buku Copernicus dengan buku ilmuwan Muslim Arab yaitu Ibn al-Syatir yang ditulis lebih dari seratus tahun sebelumnya. ${ }^{16}$

3. Astronomi untuk Penentuan Arah Kiblat / Kalibrasi

Terdapat beberapa metode untuk menentukan arah kiblat, pada penelitian ini akan membahas sebagian dari metode tersebut, yaitu kalibrasi spherical trigonometry, kalibrasi Saadoeddin Djambek,

\footnotetext{
${ }^{14}$ Al-Khailili. Jim et al.

${ }^{15}$ Lohlker Rudiger.

${ }^{16}$ Siti Nur Halimah.
} 
kalibrasi Rashdul Kiblat Global, kalibrasi Mizwala, dan kalibrasi dengan hembusan angin. Di bawah ini Tabel 1. merupakan daftar kalibrasi arah kiblat.

\section{Tabel 1. Tabel Kalibrasi Arah Kiblat}

\begin{tabular}{|c|c|c|}
\hline $\begin{array}{l}\text { No } \\
\text { • }\end{array}$ & $\begin{array}{l}\text { Metode } \\
\text { Kalibrasi }\end{array}$ & $\begin{array}{l}\text { Teknik } \\
\text { Perhitungan }\end{array}$ \\
\hline 1 & $\begin{array}{l}\text { Penentuan } \\
\text { Arah Kiblat } \\
\text { Segitiga Bola } \\
\text { (Spherical } \\
\text { Trigonometri) }\end{array}$ & $\begin{array}{l}\text { Dengan cara } \\
\text { mengetahui lokasi } \\
\text { Ka'bah (lintang } \\
\text { dan bujur), serta } \\
\text { mengetahui data } \\
\text { geografis lokasi } \\
\text { setempat, } \\
\text { kemudian } \\
\text { dihitung } \\
\text { menggunakan } \\
\text { rumus. }\end{array}$ \\
\hline 2 & $\begin{array}{l}\text { Penentuan } \\
\text { Arah Kiblat } \\
\text { Saadoeddin } \\
\text { Djambek }\end{array}$ & $\begin{array}{l}\text { Dengan cara } \\
\text { diketahuinya letak } \\
\text { Ka'bah, letak } \\
\text { lokasi yang ingin } \\
\text { ditemukan arah } \\
\text { kiblatnya, dan } \\
\text { letak kutub Utara, } \\
\text { kemudian } \\
\text { dihitung dengan } \\
\text { rumus. }\end{array}$ \\
\hline 3 & $\begin{array}{l}\text { Penentuan } \\
\text { Arah Kiblat } \\
\text { Kalibrasi } \\
\text { Rashdul } \\
\text { Kiblat Global }\end{array}$ & $\begin{array}{l}\text { Dengan rumus } \\
\text { khusus dan } \\
\text { mengandalkan } \\
\text { bayangan } \\
\text { matahari. }\end{array}$ \\
\hline 4 & $\begin{array}{l}\text { Penentuan } \\
\text { Arah Kiblat } \\
\text { Kalibrasi } \\
\text { Mizwala }\end{array}$ & $\begin{array}{l}\text { Metode ini tidak } \\
\text { menggunakan } \\
\text { rumus } \\
\text { perhitungan, } \\
\text { melainkan melalui }\end{array}$ \\
\hline
\end{tabular}

17 Habibullah Ritonga dan Arwin Juli Rakhmadi Butar-butar, 'Peran Ilmu Falak Dalam Masalah Arah Kiblat, Waktu Salat Dan Awal Bulan',

\begin{tabular}{lll}
\hline & & $\begin{array}{l}\text { peristiwa alami } \\
\text { matahari. }\end{array}$ \\
\hline 5 & $\begin{array}{l}\text { Penentuan } \\
\text { Arah Kiblat } \\
\text { dari } \\
\text { hembusan } \\
\text { angin }\end{array}$ & $\begin{array}{l}\text { Dengan cara } \\
\text { mengetahui arah } \\
\text { angin. }\end{array}$ \\
\hline
\end{tabular}

Sumber : Analisa Penulis, 2021

Pada Tabel 1. di atas dapat dilihat berbagai macam cara untuk penentuan arah kiblat. Berikut di bawah ini penjelasan secara singkat dari berbagai cara dalam penentuan arah kiblat tersebut.

a) Penentuan Arah Kiblat Segitiga Bola (Spherical Trigonometri)

Ilmu ukur segitiga bola (Spherical Trigonometri), metode ini digunakan untuk menentukan arah kiblat dengan cara mengetahui terlebih dahulu lokasi Ka'bah berdasarkan lintang dan bujur, serta mengetahui data geografis lokasi setempat, barulah kemudian dihitung menggunakan rumus. ${ }^{17,18}$

\section{b) Penentuan Arah Kiblat Saadoeddin Djambek \\ Penentuan arah kiblat Saadoeddin} Djambek, metode ini berawal dari spherical trigonometry dan rumus analogi Napier. Dimana teori dan rumus tersebut memiliki landasan ilmu Geometri untuk menentukan arah kiblat. Dalam proses penentuan arah kiblat dengan metode Saadoeddin Djambek,

Al-Marshad: Jurnal Astronomi Islam Dan Ilmu-Ilmu Berkaitan, 2.2 (2016).

$$
{ }^{18} \text { Agussani. }
$$




\section{AL-MARSHAD: JURNAL ASTRONOMI ISLAM DAN ILMU-ILMU BERKAITAN \\ ISSN 2442-5729 (print) || ISSN 2598-2559 (online) \\ http://jurnal.umsu.ac.id/index.php/almarshad \\ DOI: //doi.org/10.30596/jam.v7i1.6888 || Vol. 7, No. 1 Juni 2021}

maka perlu diketahui letak Ka'bah, letak lokasi yang ingin ditemukan arah kiblatnya, dan letak kutub Utara. ${ }^{19}$

c) Penentuan Arah Kiblat Kalibrasi

Rashdul Kiblat Global

Penentuan arah kiblat dengan

kalibrasi Rashdul Kiblat merupakan metode yang tidak terpengaruh dengan bentuk Bumi.

Metode ini dilakukan dengan rumus khusus dan mengandalkan bayangan matahari. ${ }^{20}$

d) Penentuan Arah Kiblat dengan Alat Kalibrasi Mizwala

Penentuan arah kiblat dengan sebuah alat penghitung bernama Mizwala. Mizwala adalah alat untuk menentukan arah kiblat dengan menggunakan sinar Matahari (fenomena alami matahari). ${ }^{21}$

e) Penentuan Arah Kiblat dari Hembusan Angin

Metode penentuan arah kiblat dengan hembusan angin ini ditentukan dengan mengetahui arah angin yang dinamakan Angin Shaba $\left(78,75\right.$ dan $\left.0 / 360^{\circ}\right)$, Angin Dabur (157,5 dan $\left.281,25^{\circ}\right)$, Angin Janub (78,75 dan $\left.157,5^{\circ}\right)$, serta Angin Syamal (281, 25 dan 360 derajat). ${ }^{22,23}$

${ }^{19}$ Fatmawati, 'Rumus Arah Kiblat Saadoeddin Djambek Perspektif Spherical Trigonometry', AlMarshad: Jurnal Astronomi Islam Dan Ilmu-Ilmu Berkaitan, 6.2 (2020).

20 Habibullah Ritonga dan Arwin Juli Rakhmadi Butar-butar.

21 Habibullah Ritonga dan Arwin Juli Rakhmadi Butar-butar.
Dalam aspek arsitektural, berbagai metode kalibrasi arah kiblat ini berhubungan erat dengan penentuan arah desain masjid.

B. Pengaruh Astronomi terhadap Arsitektur

Dalam penelitian yang dilakukan oleh

David A. King, membahas bahwa pada abad pertengahan terdapat ventilator pada rumahrumah di Fustat dan Kairo yang disebut Badahanj. ${ }^{24}$

Ventilator tersebut tidak mengarah sejajar ke arah utara secara astronomis, namun terbuka ke arah tegak lurus ke arah matahari terbit di pertengahan musim dingin. Kemudian selanjutnya ditemukan kembali fakta bahwa arah ventilator tegak lurus ke arah kiblat atau Mekah di Kairo pada abad pertengahan. Terdapat fakta lainya pula yang membahas bahwa orientasi ventilator ini juga berdasarkan alasan estetika, hal ini terlihat pada seluruh Kota Fatimiyah al-Qahira. Ventilator tersebut dibangun di sepanjang kanal Laut Merah Firaun yang secara kebetulan juga sejajar dengan arah kiblat yang ditentukan secara astronomis. Selain karena estetika, arah ventilator ini juga dipengaruhi arah angin dalam cerita rakyat

22 Nur Hidayatullah el-Banjari, 'Menentukan Arah Kiblat Dengan Hembusan Angin', Al-Marshad: Jurnal Astronomi Islam Dan Ilmu-Ilmu Berkaitan, 2.1 (2016).

23 Agussani.

${ }^{24}$ D. A King, 'Architecture and Astronomy: The Ventilators of Medieval Cairo and Their Secrets', Journal of the American Oriental Society, 104.1 (1984), 97-133. 


\section{AL-MARSHAD: JURNAL ASTRONOMI ISLAM DAN ILMU-ILMU BERKAITAN \\ ISSN 2442-5729 (print) || ISSN 2598-2559 (online) \\ http://jurnal.umsu.ac.id/index.php/almarshad \\ DOI: //doi.org/10.30596/jam.v7i1.6888 || Vol. 7, No. 1 Juni 2021}

mesir pada abad pertengahan. ${ }^{25}$

Tabel astronom pada abad pertengahan memiliki keterkaitan dengan ventilator (Badahanj). Tabel-tabel ini disusun oleh astronom terkenal di Fatimiyah Ibn Yunus dan yang lainnya ditambahkan oleh berbagai astronom Mamluk. Kemudian diantaranya terdapat tabel yang menunjukkan ketinggian matahari dalam derajat ketika matahari searah dengan badahanj. Analisis tabel tersebut menunjukkan bahwa bagian belakang badahanj dimaksudkan agar sejajar dengan arah matahari terbit pada pertengahan musim dingin.

Dalam buku yang ditulis David A. King juga dijelaskan bahwa terdapat sejumlah besar teks Arab abad pertengahan yang membahas tentang astronomi rakyat, dan menemukan pernyataan tentang angin, jumlah, nama dan arah hembusan angin tersebut. Terdapat empat angin utama (telah disebutkan pada subbab sebelumnya). (1) Angin Shaba, yaitu angin yang berasal dari Timur (Sic, antara Timur dan Utara). (2) Angin Dabur, yaitu angin yang bertiup dari antara Barat dan kutub Selatan. (3) Angin Syamal, yaitu angin yang bertiup dari antara kutub Utara dan Barat. (4) Angin Janubiya, yaitu angin yang berasal dari antara kutub Selatan dan Timur.
Garis besar dalam pembahasannya, David A. King telah menunjukkan bahwa berbagai orientasi masjid di Kairo abad pertengahan merupakan ekpresi dari keinginan agar masjid menghadap ke Ka'bah. Kemudian orientasi kota fatimiyah al-Qahira ditentukan dari kanal Laut Merah Pharonic (karena faktor topografi) yang secara kebetulan tegak lurus dengan kiblat al-sahaba yang ditentukan secara astronomis menghadap dinding barat laut Ka'bah. Kemudian orientasi badahanj yang hilang di Kairo abad pertengahan. ${ }^{26}$

\section{Kesimpulan}

Perjalanan perkembangan ilmu astronomi sejak masa golden age diutamakan dalam penentuan sistem kalender, dan untuk menentukan arah kiblat. Dari hal ini berkembang pengetahuan tentang teknologi, pengetahuan tentang tata surya, hingga berbagai metode untuk menentukan arah kiblat.

Kajian astronomi Islam pada masa golden age memiliki implikasi terhadap bidang arsitektur diantaranya dalam penentuan arah bangunan baik bangunan keagamaan yang terkait dengan ka'bah dan peribadatan umat muslim, maupun arah

\footnotetext{
$$
{ }^{26} \text { King. }
$$

${ }^{25}$ King.
} 


\section{AL-MARSHAD: JURNAL ASTRONOMI ISLAM DAN ILMU-ILMU BERKAITAN \\ ISSN 2442-5729 (print) || ISSN 2598-2559 (online) \\ http://jurnal.umsu.ac.id/index.php/almarshad \\ DOI: //doi.org/10.30596/jam.v7i1.6888 || Vol. 7, No. 1 Juni 2021}

bangunan umum yang terkait dengan arah mata angin (pencahayaan dan termal).

Berdasarkan kesimpulan tersebut maka para ilmuwan dibidang arsitektur dan para praktisi arsitek dapat terus mengembangkan inovasi dan keilmuan arsitektur yang dihubungkan dengan astronomi di masa mendatang.

\section{Daftar Pustaka}

Adi Damanhuri, 'Sistem Kontrol Teleskop Meade LX-600 Dengan Aplikasi Open Source', Al-Marshad, 5.2 (2019)

Agussani, 'Socio-Political Aspects In The Development Of Astronomy In The Astronomy In The World', in IJIRAS, 2020

Akkach Samer, 'ILM Science, Religion and Art in Islam (Australia: University of Adelaide Press, 2019)

Akrim, 'Nilai-Nilai Pendidikan Islam Dalam Observatorium', Al-Marshad, 6.1 (2020)

Al-Khailili. Jim et al., Science in a Golden Age - Astronomy: The Science of the Stars, 2015

$<$ https://www.youtube.com/watch?v=3c VfyurIFvM>

Anto Aprianto, 'Kesejahteraan Umaan Dan The Golden Age of Islam Telaah Historis Pemberdayaan Masyarakat Di Masa Khalifah Harun Al-Rasyid',
ICODEV, $1.1(2020)$

Fatmawati, 'Rumus Arah Kiblat Saadoeddin Djambek Perspektif Spherical Trigonometry', Al-Marshad: Jurnal Astronomi Islam Dan Ilmu-Ilmu Berkaitan, 6.2 (2020)

Habibullah Ritonga dan Arwin Juli Rakhmadi Butar-butar, 'Peran Ilmu Falak Dalam Masalah Arah Kiblat, Waktu Salat Dan Awal Bulan', Al-Marshad: Jurnal Astronomi Islam Dan Ilmu-Ilmu Berkaitan, 2.2 (2016)

Irvan dan Leo Hermawan, 'Mengenal JenisJenis Teleskop Dan Penggunaannya', Al-Marshad, 5.1 (2019)

King, D. A, 'Architecture and Astronomy: The Ventilators of Medieval Cairo and Their Secrets', Journal of the American Oriental Society, 104.1 (1984), 97-133

Lohlker Rudiger, 'Global History: Understanding Islamic Astronomy.', Acta Via Serica, 4.2 (2019), 97-118

Muhammad Qorib, 'Aspek Sosial-Intelektual Observatorium Dalam Islam', $\mathrm{Al}$ Marshad, 5.1 (2019)

Nur Hidayatullah el-Banjari, 'Menentukan Arah Kiblat Dengan Hembusan Angin', Al-Marshad: Jurnal Astronomi Islam Dan Ilmu-Ilmu Berkaitan, 2.1 (2016)

Riyadi, H. Fuad, 'Perpustakaan Bayt Al Hikmah "The Golden Age of Islam", LIBRARIA: Jurnal Perpustakaan, 2.1 
(2014)

Siti Nur Halimah, 'Benang Merah Penemu

Heliosentris: Kajian Pemikiran Ibn Al-

Syatir', Al-Marshad: Jurnal Astronomi

Islam Dan Ilmu-Ilmu Berkaitan, 4.1

(2018) 